\title{
FC1-91E122781
}

New Hampshire Governor's

$$
\begin{aligned}
& \text { Office of Energy and } \\
& \text { Community Services } \\
& \partial 0 E|E T| 22781--T \mid
\end{aligned}
$$

\section{State Heating Oil and Propane Program Final Report 1995-96 Heating Saeson}

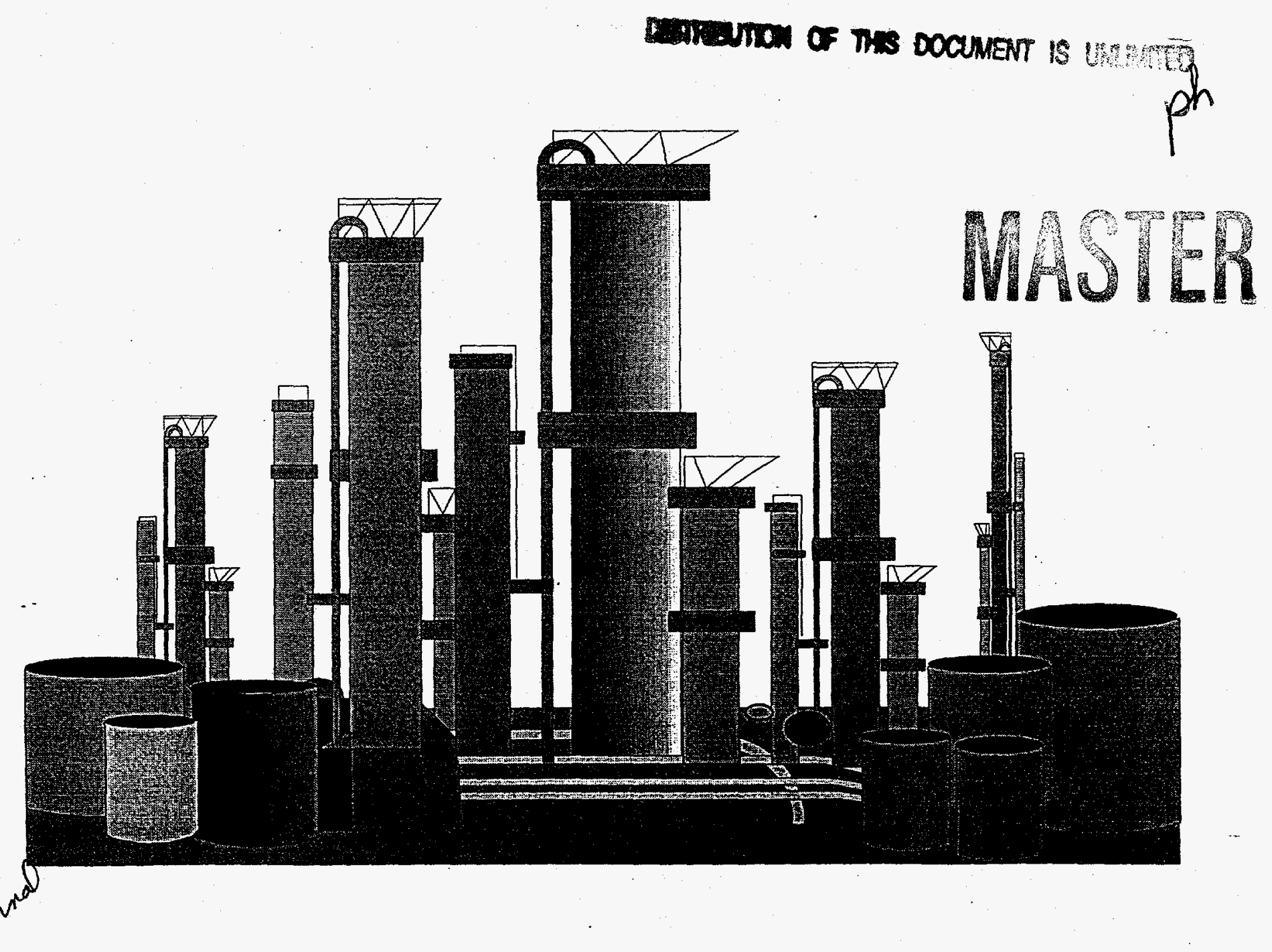




\section{DISCLAIMER}

This report was prepared as an account of work sponsored by an agency of the United States Government. Neither the United States Government nor any agency thereof, nor any of their employees, make any warranty, express or implied, or assumes any legal liability or responsibility for the accuracy, completeness, or usefulness of any information, apparatus, product, or process disclosed, or represents that its use would not infringe privately owned rights. Reference herein to any specific commercial product, process, or service by trade name, trademark, manufacturer, or otherwise does not necessarily constitute or imply its endorsement, recommendation, or favoring by the United States Government or any agency thereof. The views and opinions of authors expressed herein do not necessarily state or reflect those of the United States Government or any agency thereof. 


\section{DISCLAMMER}

Portions of this document may be illegible in electronic image products. Images are produced from the best available original document. 


\section{INTRODUCTION}

The following is a summary report of the New Hampshire Governor's Office of Energy and Community Services (ECS) participation in the State Heating Oil and Propane Program (SHOPP) for the 1995/96 heating season. SHOPP is a cooperative effort, linking energy offices in East Coast and Midwest states, with the Department of Energy (DOE), Energy Information Administration (EIA) for the purpose of collecting retail price data for heating oil and propane. The program funded by the participating state with a matching grant from DOE.

SHOPP was initiated in response to congressional inquires into supply difficulties and price spikes of heating oil and propane associated with the winter of 1989/90. This is important to New Hampshire because heating oil controls over $55 \%$ of the residential heating market statewide. Propane controls $10 \%$ of the heating market statewide and is used in rural areas where Natural Gas is not available. The popularity of propane continues to grow in New Hampshire and should continue to do so in the future. Any disruption in supply of these heating fuels to New Hampshire could cause prices to skyrocket and leave many residents in the cold.

\section{NH RESIDENTIAL HEATING FUEL USE Households by Percentage - 1995/96 Heating Season}

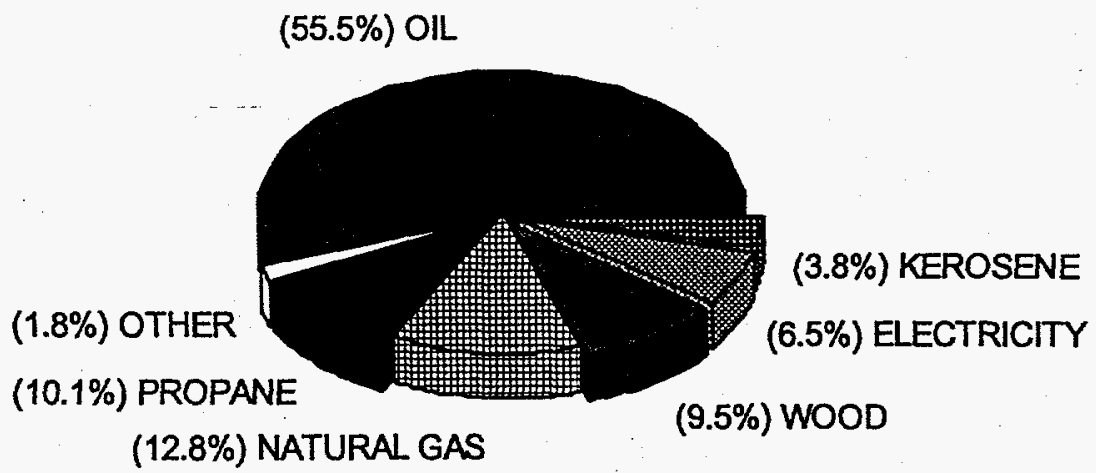


SHOPP Final Report

$1995 / 96$

Page 2

\section{$\because$ SHOPP DESCRIPTION.}

EIA provides ECS with a list of oil and propane retailers that serve customers in New Hampshire. In turn ECS conducts phone surveys twice per month from October through March to determine the average retail price for each fuel. Data collected by ECS is entered into the Petroleum Electronic Data Reporting Option (PEDRO) and transmitted via modem to EIA. The results of the state retail price surveys along with wholesale prices, supply, production and stock levels for oil, and propane are published by EIA in the Weekly Petroleum Status Report. Data is also published electronically via the internet or through the Electronic Publication System.

In addition to publication by DOE/EIA, the survey results are a valuable public information tool in New Hampshire. After the first survey of each month, ECS issues a press release with the current and historical average statewide prices for oil and propane (see appendix). Print, radio and television media report on these prices regularly. This often generates follow-up interviews and calls from the general public business and others.

ECS has participated in joint programs with EIA in the past. Most recently in 1987/88, ECS collected price and supply data for heating oil. Retail oil price data has been collected by ECS on a monthly basis since 1976.

ECS has participated in SHOPP since its inception for the 1990/91 heating season and plans to continue participation for the $1995 / 96$ heating season as well.

ECS also tracks price and supply data from published sources such as EIA reports, the Oil Daily, the Wall Street Journal, and American Petroleum Institute reports.

The following sections summarize ECS participation in SHOPP for the 1995/96 heating season. 
SHOPP Final Report

$1995 / 96$

Page 3

\section{WEATHER}

Temperature and heating degree data for the 1995/96 heating season in New Hampshire indicate a normal winter. However, compared to last winter when temperatures were well above normal there was a significant difference. According to climatological data from the National Weather Service the average temperatures in the first half of the heating season was 4.2 degrees above average in October, 2.9 degrees below average in November and 1.4 degrees below. normal in December. In terms of heating degree days (HDD) the difference is clearly seen. From October through December, New Hampshire had over 18\% more HDD than last heating season. All of the gain in HDD occurred in November and December.

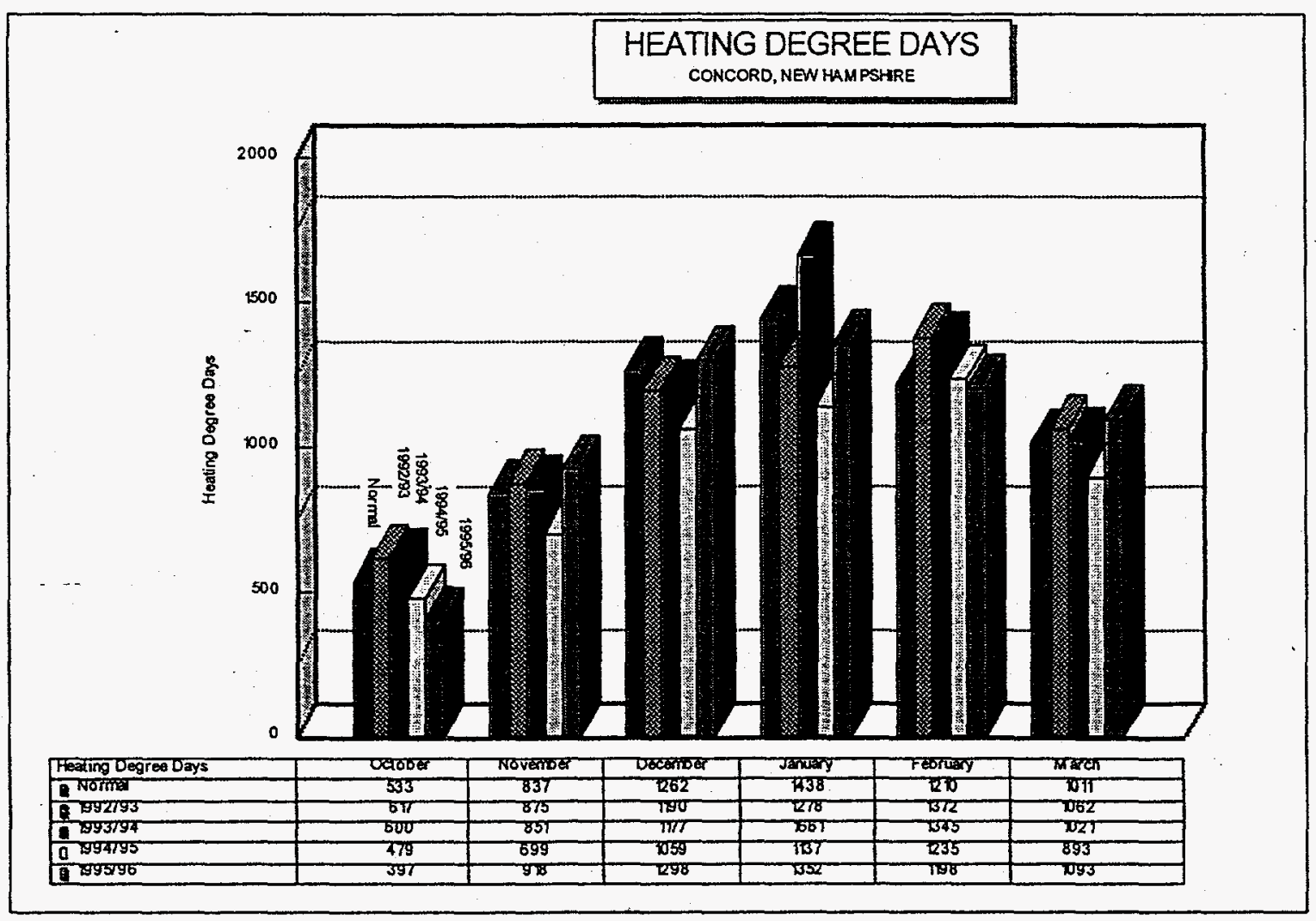


. SHOPP Final Report $1995 / 96$

Page 4

The second half of the heating season largely mirrored the first half. In January the average temperature was 2.6 degrees below normal. Temperatures were slightly above normal in February and lower than normal in March. Overall there were 11\% more HDD this winter than last.

\section{PROPANE}

SUPPLY

Stocks of propane in PADD I fell mostly within their normal range during the first half of the heating season according to monthly stock figures from the Winter Fuels Report. However, PADD III which supplies New England with much of it s propane had stock levels below the 3 year average for much of the quarter. However, cold weather caused large draw downs in December and January. By the end of January stocks had fallen to historic lows. Imports into New England in January were far above the previous year. A late cold snap left inventories at record low levels by the end of the heating season.

\section{PRICES}

Prices were stable in New Hampshire through October and November but started to climb as colder weather increased stock draw downs. The price increased by 6 cents in December and then another 8 cents through the March 18 survey. A cold snap at the end of the heating season combined with record low stocks, to push prices upward at a time when prices are usually in decline.

\section{SHOPP - NEW HAMPSHIRE AVERAGE RETAIL PROPANE PRICE 1995-96 HEATING SEASON.}

\begin{tabular}{|l|c|c|c|c|c|c|c|c|c|c|c|}
\hline $10 / 02$ & $10 / 16$ & $11 / 06$ & $11 / 20$ & $12 / 04$ & $12 / 18$ & $01 / 01$ & $01 / 15$ & $02 / 05$ & $02 / 19$ & $03 / 04$ & $03 / 18$ \\
\hline$\$ 1.143$ & $\$ 1.138$ & $\$ 1.144$ & $\$ 1.145$ & $\$ 1.145$ & $\$ 1.154$ & $\$ 1.217$ & $\$ 1.253$ & $\$ 1.269$ & $\$ 1.284$ & $\$ 1.300$ & $\$ 1.303$ \\
\hline
\end{tabular}


. SHOPP Final Report

$1995 / 96$

Page 5

\section{OUTLOOK}

Propane stocks were at record lows at the end of the heating season while prices were high. Stocks this low could impact the ability of the propane industry to build stocks adequately for the 96-97 heating season. Low stocks at the beginning of the heating season could place upward pressure on prices particularly during cold snaps. This situation will need to be monitored closely.

\section{HEATING OIL}

\section{SUPPLY}

Stocks sagged below the three year average range throughout the heating season. Most of the stock shortfall took place in PADD I. The situation worsened as the heating season progressed and resulted in record low stocks by the end of the heating season.

\section{PRICES}

Retail prices recorded relatively small seasonal gains in October and November rising by about 5 cents. However the price rose by almost 14 cents in December and January with lower stocks pushing prices upward. By the end the season the retail price in New Hampshire reached about $\$ 1.00$ per gallon. Historically, late heating season prices hadn't been this high since 1985 .

\section{SHOPP - NEW HAMPSHIRE AVERAGE RETAIL HEATING OIL PRICE 1995-96 HEATING SEASON.}

\begin{tabular}{|l|l|l|l|l|l|l|l|l|l|l|l|}
\hline $10 / 02$ & $10 / 16$ & $11 / 06$ & $11 / 20$ & $12 / 04$ & $12 / 18$ & $01 / 01$ & $01 / 15$ & $02 / 05$ & $02 / 19$ & $03 / 04$ & $03 / 18$ \\
\hline$\$ .800$ & $\$ .799$ & $\$ .801$ & $\$ .822$ & $\$ .849$ & $\$ .910$ & $\$ .949$ & $\$ .985$ & $\$ .977$ & $\$ .993$ & $\$ .998$ & $\$ .999$ \\
\hline
\end{tabular}


SHOPP Final Report

$1995 / 96$

Page 6

\section{OUTLOOK}

With record low stocks at the end of the heating season, refiners and distributors will be challenged to bring stocks to historically normal levels for the start of the 1996-97 heating season. Just-in time inventory practices being employed now will make it less necessary to keep large amounts fuel on hand. However, this will make the system more susceptible to price instability without the comfort of having a large buffer of stocks to moderate price movements during times of high consumption.

\section{ADMINISTRATION}

The heating oil dealers were very cooperative this year as they have been in past years. No difficulties were encountered collecting prices except for an occasional problem of getting calls returned promptly. Propane companies were for the most part cooperative. ECS continues to use 1000 gallons annual consumption as a benchmark for price and will continue to do so. However, even with the benchmark, prices vary widely among dealers.

ECS is still experiencing problems with the use of PEDRO. ECS operates on a Windows based Network and PEDRO, cannot operate on our network because of problems with having enough conventional memory to operate the Network and PEDRO at the same time. So, in order top operate PEDRO it is necessary to $\log$ off the network, load different the config and autoexec files and then reboot the computer. This is inconvenient and time consuming. Particularly when you must log off and then return later. In addition, it is also impossible to print reports from PEDRO because printing must be routed through the network. To remedy this, a Lotus spread sheet was developed to collect prices and retain data. PEDRO now is used only to transfer data. The Windows version that is being developed for use on a network will be very helpful. 
SHOPP Final Report

$1995 / 96$

Page 7

\section{SHOPP RELATED ACTIVITIES DURING THE 1995-96 HEATING SEASON}

As always there was significant interest from the press and the general public about SHOPP. Print and broadcast media regularly reported on the results of the SHOPP surveys. News reports increased consumer awareness and the amount calls to ECS. Through this program, ECS has become the source for information on the heating oil and propane industries in New Hampshire.

The Governor's Office of Energy and Community Services participates in a number of "spin off" activities relating to SHOPP. Every October. the Governor's Petroleum Task brings together heating fuel retailers and wholesalers representing the heating oil, propane and natural gas industries in New Hampshire. These individuals provide an assessment of the upcoming heating season and provide a valuable link between ECS and the heating fuel industry on all levels.

ECS also took over responsibility from New York State for sponsoring a regional meeting highlighting propane industry issues. The meeting called the Northeast Regional Propane Task Force meeting includes government and propane industry representatives from all of the New England states and New York to asses the upcoming season and to tackle issues that effect the industry where states could have an impact. The meeting was held in Boston MA and based on its success will be held again along with a separate regional meeting for heating oil.

\section{CONCLUSION}

SHOPP has become an integral part of the programming activities for ECS. What originally started as a data collection program has grown into something larger and provides a valuable service to the citizens of New Hampshire. ECS will once again participate in this program for the 1996-97 heating season. ECS will also continue to use SHOPP as the center of 
. - SHOPP Final Report

1995/96

Page 8

activities in the effort to bring accurate price information to citizens, industry, government and policy makers. 